\title{
$100 \mathrm{kWh}$ SMES モデルコイルー交流損失一
}

浜島高太郎, 花井 哲*1, 和智 良裕*1, 京藤 誠*1, 嶋 田 守*1, 小野 通隆*1, 島田 一人*1, 櫛田 ルナ*1, 手 塚 勝*1, Nicolai MARTovetSKY*2, Jon ZBASNIK*2, Jeffrey Moller*2, 平野 直樹*3, 篠田 公之*3, 山本 政弘*4, 高野 一郎*4, 姫 野 隆*4, 佐 藤 隆*5

\author{
山口大学工学部 宇部市常盤台 2-16-1 \\ *1 (秼) 東芝 横浜市鶴見区末広町 2-4 \\ ${ }^{* 2}$ Lawrence Livermore National Laboratory, L-641, 7000 East Ave., Livermore, CA 94550, USA \\ *3 中部電力秼電力技術研究所 名古屋市緑区大高町字北関山 20-1 \\ *4 財国際超電導産業技術研究センター 東京都港区新橋 5-34-3 \\ *5 核融合科学研究所 土岐市下石町 $322-6$
}

(1999 年 3 月 16 日受理)

\section{Test Results of the $100 \mathrm{kWh}$ SMES Model Coil-AC Loss Performance- \\ Takataro Hamajima, Satoshi HanaI, ${ }^{* 1}$ Yoshihiro WachI, ${ }^{* 1}$ Makoto Kyoto, ${ }^{* 1}$ Mamoru Shimada, ${ }^{* 1}$ Michitaka OnO, ${ }^{* 1}$ Kazuhiko Shimada, ${ }^{* 1}$ Luna KushidA, ${ }^{* 1}$ Masaru TeZuka, ${ }^{* 1}$ Nicolai Martovetsky, ${ }^{* 2}$ Jon ZBASnik, ${ }^{* 2}$ Jeffrey Moller, ${ }^{* 2}$ Naoki Hirano, ${ }^{* 3}$ Kimiyuki Shinoda, ${ }^{* 3}$ Masahiro Yamamoto, ${ }^{* 4}$ Ichiro Takano, ${ }^{* 4}$ Takashi Himeno*4 and Takashi SATOW*5 \\ Faculty of Engineering, Yamaguchi University, 2-16-1 Tokiwadai, Ube 755-8611 \\ ${ }^{* 1}$ Toshiba Corporation, 2-4 Suehiro-cho, Tsurumi-ku, Yokohama 230-0045 \\ ${ }^{* 2}$ Lawrence Livermore National Laboratory, L-641, 7000 East Ave., Livermore, CA 94550, USA \\ ${ }^{* 3}$ Chubu Electric Power Co., Inc., 20-1 Oodaka-cho, Midori-ku, Nagoya 459-8001 \\ ${ }^{* 4}$ International Superconductivity Technology Center, 5-34-3 Shinbashi, Minato-ku, Tokyo 105-0004 \\ *5 National Institute for Fusion Science, 322-6 Oroshi, Toki, Gifu 509-5292}

(Received March 16, 1999)

\section{Synopsis:}

In order to establish a technology needed for a small-scale $100 \mathrm{kWh}$ SMES device, a SMES model coil was fabricated. Performance tests were carried out at the Japan Atomic Energy Research Institute (JAERI) in 1996. After that, the coil was installed in facilities of the Lawrence Livermore National Laboratory (LLNL) and tested in 1998, in collaboration between Japan and the United States. The AC loss results at LLNL were in good agreement with those at JAERI. It was reconfirmed from the results that the coupling loss of the coil consists of two components with short and long time constants. We found out from the signals of Hall probes that the current loops with long decay time constants were induced in the CIC conductor. These loops could enhance additional $\mathrm{AC}$ loss in the coil. To reduce the AC loss, we made small-sized CIC conductor of strands having a $\mathrm{CuNi}$ surface, a fabricated the small coil. The measured AC loss of the small coil was reduced to about $1 / 6$. The CuNi surface on the strands was demonstrated to be effective to reduce AC loss in the coil.

Keywords: SMES, AC losses, cable-in-conduit conductors, forced flow 


\section{1.はじめに}

超電導電力貯蔵装置 (SMES) は, 超電導体の抵抗 がゼロである特徴を利用して超電導コイルに電流を供 給し, 磁気エネルギーの形で電力を貯蔵して必要に応 じてエネルギーの出し入れを行う装置である。電力の 直接の入出力により高い貯蔵効率, 速い応答速度が得 られ，パワーエレクトロニクス素子と組み合わせて有 効・無彸電力の独立制御などが可能である。そのた め, kWh から GWh 級の幅広い規模で, 電力系統の 負荷変動補償や系統安定度向上から負荷平準化までの 多様な機能を持ち, 将来の電力系統において重要な役 割を果たすものと期待される

通産省資源エネルギ一庁は，日本に抢ける本格的な SMES 開発の第一歩として, 小規模 SMES パイロッ トプラント(電力貯蔵容量 $100 \mathrm{kWh}$ 級, 出力 20 MW）建設に必要な要素技術の確立のためのプロジ エクトを 1991 年より 8 年計画で開始した ${ }^{2 \sim 4)}$ 。(財国際 超電導産業技術研究センター（ISTEC）が本プロジ エクトを受託し, これに学識経験者・電力会社・メー カーが参画して推進している。その一環として, 開発 要素の最も多いSMES モデルコイルを製作し，1996 年に注日本原子力研究所（原研）との共同研究で基本 的な性能評価試験を実施した。その一連の試験結果は すでに報告した ${ }^{5 \sim 11}$ 。

その後, SMES モデルコイルは, 日米の国際協力 の下に; 1997 年に米国ローレンス・リバモア国立研 究所 (LLNL) へ輸送され，LLNLの試験設備に組 み込まれた。1998年に繰り返し通電, 機械強度, 交 流損失特性などの性能評価試験が実施された。

本論文では，LLNLにおけるSMES モデルコイル の一連の性能評価試験のうち, 主に交流損失特性につ いて述べる。原研で得られた交流損失結果はすでに報 告して扔り，そこでは次の結論を得た ${ }^{11)}$ 。 SMES モ デルコイルのヒステリシス損失は素線のそれの本数倍 に一致した。結合損失は多くの時定数から構成され， それを 2 つの時定数で代表すると，220 ms 程度の短 時定数と, $30 \mathrm{~s}$ 程度の長時定数の成分で表すことがで きた。このうちの短時定数の成分は短尺導体の結合損 失測定結果にほぼ一致した。一方，長時定数の成分は コイルにして初めて現れた損失で，約 $4 \mathrm{~m}$ 程度の特 性長定有する結合電流ループが導体内で発生するもの と考光られた。

このような結合損失の長時定数成分は核融合科学研

Voi. 34 No. 6 (1999)
究所の LHD 用ポロイダルコイルの交流損失試験でも 観測された。そこでは，結合電流ループとして $124 \mathrm{~s}$ 程度の時定数と $11.5 \mathrm{~m}$ 程度の特性長を持つループが 推定された ${ }^{22,13)}$ 。

LLNLに打ける交流損失試験では，原研で得られ たこれらの諸特性を確認するために，通電電流波形を 種々に変化させて交流損失を測定した。さらに，長時 定数成分を直接観測するために, SMES モデルコイ ルにホール素子を取り付けて、ループ電流による磁界 の減衰を測定した。

最後に，将来のSMES に用いる大型導体の有力な 候補の 1 つとして，交流損失の低減を図った改良導体 を提案した。その導体を製作して，短尺特性を調べ た。併せて, 同じ素線を用いた $1 / 4$ 縮小断面ケーブ ル導体で小型コイルを製作し，コイルとしての交流損 失特性を測定し, 改良導体の有効性を検討したので報 告する。

\section{SMES モデルコイルの交流損失試験}

SMES モデルコイルの主要諸元を Table 1 に示す。 装置に関する詳細な報告は参考文献(日述べられてい るので，ここでは，LLNLでの交流損失測定方法お よびそれに必要な事項についてのみ述べる。SMES モデルコイルはケーブル・イン・コンジット (CIC)

Table 1 Main parameters of the SMES model coil.

Conductor

\begin{tabular}{ll}
\hline Type & Cable-in-conduit \\
Conduit outer dimension & $25.4 \times 27.8 \mathrm{~mm}$ \\
Thickness & $2.3 \mathrm{~mm}$ \\
Void fraction & $36 \%$ \\
Strand material & $\mathrm{NbTi} / \mathrm{Cu} / \mathrm{CuNi}$ \\
Diameter & $0.62 \mathrm{~mm}$ \\
Configuration & $3 \times 3 \times 3 \times 3 \times 3 \times 4=972$
\end{tabular}

Coil

$\begin{array}{ll}\text { Inner diameter } & 2.76 \mathrm{~m} \\ \text { Outer diameter } & 3.34 \mathrm{~m} \\ \text { Height } & 0.234 \mathrm{~m} \\ \text { Turns } & 11 \times 8=88 \\ \text { Inductance } & 39.6 \mathrm{mH} \\ \text { Operating current } & 20 \mathrm{kA} \\ \text { Stored energy } & 7.92 \mathrm{MJ} \\ \text { Maximum magnetic field } & 2.84 \mathrm{~T} \text { at } 20 \mathrm{kA}\end{array}$


導体で巻線された 4 ダブルパンケーキで構成され, 超 臨界圧へリウム（SHe）冷媒は, 各ダブルパンケーキ 内側の内径渡り部分から供給され，上下のパンケーキ を並列に流れて，外周のパンケーキ間接続部から排出 される。

LLNL での交流損失測定には原研の場合と同じエ ンタルピー法を用いた。すなわち, 通電中の各パンケ 一キの入口・出口の SHe 温度, 圧力, 流量を測定し, 入口・出口のSHe エンタルピーを求め, 両者のエン タルピー差を時間積分して交流損失量を求めた。その 際の時間積分は，SHeの状態が通電する前の状態に なるまで十分に長い時間をとった。また，エンタルピ 一法で得られた交流損失量の補正は，冷媒配管の入口 に巻き付けたヒータの入熱と比較して較正した。測定 は数千秒の長い時間積分で行うため，その期間中に冷 媒流量などが変動する。そのため, 測定結果には土1 $\mathrm{kJ}$ 程度の誤差が伴うことを考慮する必要がある。

LLNLでの交流損失測定結果のみを Table 2 亿示 す。表中のヒステリシス損失は原研での試験結果を使
用した。また，結合損失は全損失からヒステリシス揁 失を除いた分とした。

全交流損失と最大磁界変化率の関係を Fig. 1 亿示 す。図中の黑塗りの測定点は原研での測定デー夕を表 す11)。図から, LLNL 測定結果は, 原研での測定値, およびその磁界変化率に対して飽和する特性が比較的 良く一致している。同じ磁界変化率での交流損失の差 は，台形波電流波形のフラットトップ時間の長さの違 いによるものである。

また, 本コイル試験は, 本格的な大型超電導マグネ ットを用いて日米で同じ計測を行った数少ないケース である。温度・流量などの冷媒の条件や, 計測装置か 異なったにもかかわらず，同じ測定原理で同じコイル の交流損失を測定して，ほぼ同じ值が得られたこと は，本エンタルピー法の国際的な標準化が可能なこと を示唆している。

\section{SMES モデルコイルの結合損失}

結合損失 $Q_{c}$ は，磁界の立ち上げ時間の関数である

Table 2 AC loss data at LLNL.

\begin{tabular}{ccccccc}
\hline $\begin{array}{c}\text { Test } \\
\text { number }\end{array}$ & $\begin{array}{c}\text { Flat top } \\
\text { current } \\
(\mathrm{kA})\end{array}$ & $\begin{array}{c}\text { Ramp rate } \\
(\mathrm{A} / \mathrm{s})\end{array}$ & $\begin{array}{c}\text { Flat top } \\
\text { time } \\
(\mathrm{s})\end{array}$ & $\begin{array}{c}\text { AC loss } \\
Q_{\mathrm{ac}} \\
(\mathrm{kJ})\end{array}$ & $\begin{array}{c}\text { Hysteresis } \\
\text { loss } \\
Q_{\mathrm{h}}(\mathrm{kJ})\end{array}$ & $\begin{array}{c}\text { Coupling } \\
\text { loss } \\
Q_{\mathrm{c}}(\mathrm{kJ})\end{array}$ \\
\hline prc 01113 & 5.26 & 199 & $0^{*}$ & 1.86 & 0.53 & 1.33 \\
prc 01114 & 5.24 & 201 & 40 & 3.23 & 0.52 & 2.71 \\
prc 01275 & 9.94 & 187 & 0 & 6.40 & 0.99 & 5.41 \\
prc 01165 & 9.60 & 188 & 300 & 8.73 & 0.96 & 7.77 \\
prc 01287 & 19.69 & 23.3 & 300 & 9.41 & 1.97 & 7.44 \\
prc 01172 & 19.75 & 47.3 & 0 & 8.90 & 1.98 & 6.92 \\
prc 01175 & 19.74 & 47.3 & 100 & 8.20 & 1.97 & 6.23 \\
prc 01168 & 19.75 & 188 & 0 & 20.4 & 1.98 & 18.4 \\
prc 01169 & 19.75 & 188 & 30 & 19.4 & 1.98 & 17.4 \\
prc 01166 & 19.76 & 188 & 300 & 26.9 & 1.98 & 24.9 \\
prc 01170 & 19.81 & 473 & 0 & 36.3 & 1.98 & 34.3 \\
prc 01171 & 19.74 & 472 & 100 & 36.9 & 1.97 & 34.9 \\
prc 01178 & 19.99 & 944 & 0 & 45.0 & 2.00 & 43.0 \\
prc 01179 & 19.94 & 950 & 30 & 51.6 & 1.99 & 49.6 \\
prc 01273 & 19.66 & 950 & 100 & 50.2 & 1.97 & 48.2 \\
prc 01191 & 24.48 & 189 & 300 & 29.5 & 2.45 & 27.1 \\
prc 01193 & 29.35 & 47.3 & 300 & 15.5 & 2.94 & 12.6 \\
prc 01277 & 29.46 & 189 & 0 & 39.0 & 2.95 & 36.1 \\
prc 01279 & 29.44 & 188 & 300 & 40.1 & 2.94 & 37.2 \\
prc 01278 & 34.33 & 47.2 & 0 & 23.2 & 3.43 & 19.8 \\
\hline
\end{tabular}

* Flat top time 0 means triangle waveform. 


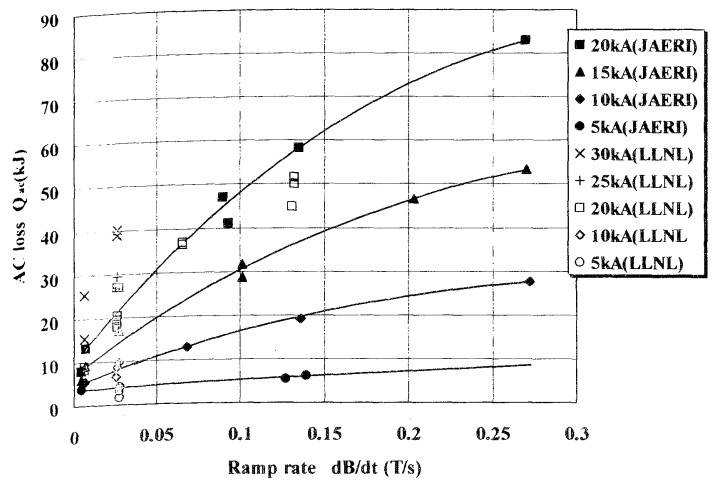

Fig. 1 AC losses in the SMES model coil as a function of ramp rate with parameter of flat top currents.

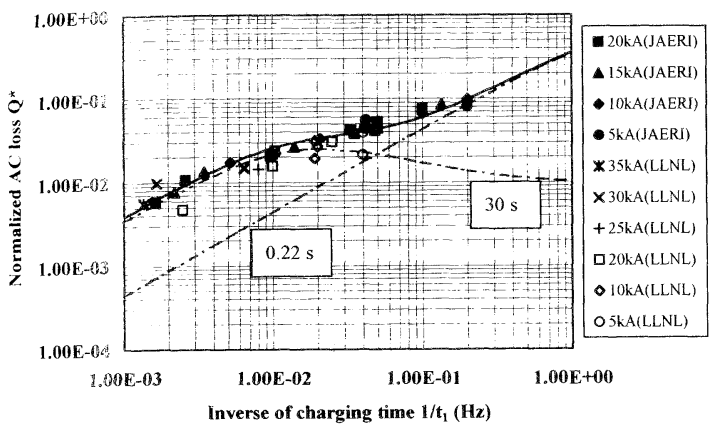

Fig. 2 Normalized coupling loss as a function of inverse charging time. The loss consists of two major time constants; $Q^{*}=Q_{1}+Q_{2} \times$ 0.06 . The time constant of $Q_{1}$ is about 0.22 $\mathrm{s}$, and that of $Q_{2}$ about $30 \mathrm{~s}$.

規格化損失 $Q^{*}$ を用いて, 次式で表すことができ る ${ }^{14)}$ 。

$$
Q_{\mathrm{c}}=Q^{*}\left(\frac{2}{\mu_{0}} \sum_{i} B_{\mathrm{m} i}{ }^{2} V_{i}\right)
$$

ここで， $Q^{*}$ は単発台形波の場合次式で与えられる。

$$
Q^{*}=\zeta\left\{2+\zeta\left(1-\mathrm{e}^{-1 / 5}\right)\left(\mathrm{e}^{-1 / \zeta-1 / \xi}-\mathrm{e}^{-1 / \xi}-2\right)\right\}
$$

ただし, $\zeta=\tau_{\mathrm{c}} / t_{1}, \quad \xi=\tau_{\mathrm{c}} / t_{2}, \quad \tau_{\mathrm{c}}=\frac{1}{2} \frac{\mu_{0}}{\rho_{\perp}}\left(\frac{L_{\mathrm{p}}}{2 \pi}\right)^{2}, \quad B_{\mathrm{m} i}$,

$V_{i}$ は $i$ 番目の要素における最大磁界と体積を表し, 体積要素は素線の体積を用いる。また， $t_{1}$ は立ち上げ 時間， $t_{2}$ はフラットトップの時間， $L_{\mathrm{p}}$ はツイストピ ツチを表す。

Vol. 34 No. 6 (1999)

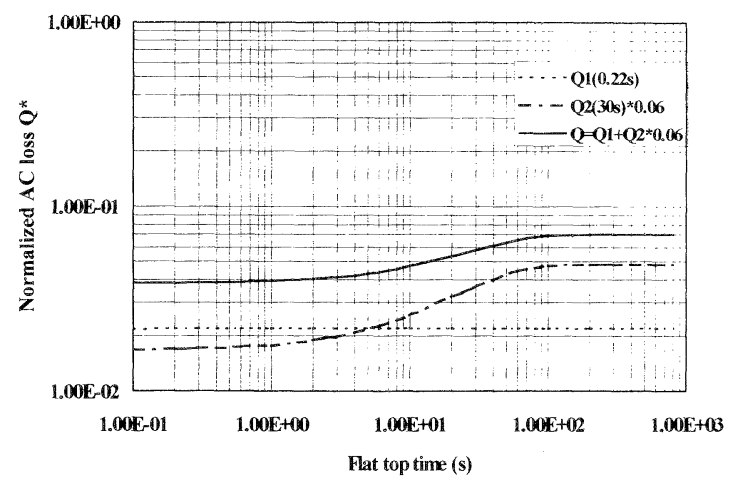

Fig. 3 Normalized AC loss as a function of flat top time in the case of a $1 \mathrm{kA} / \mathrm{s}$ ramp rate.

規格化損失 $Q^{*}$ を磁界の立ち上げ時間の逆数（周波 数）に対してプロットした結果をFig. 2 に示す。あ わせて, 原研の試験結果を黒塗りの測定点として示 す11)。図から，規格化した交流損失はほほ 1 つの曲線 上にある。すなわち, 結合損失がほぼ立ち上げ時間の 関数であることを意味している。この曲線（実線）を 2 つの結合損失の時定数に分解すると, 約 $0.22 \mathrm{~s}$ (一 点鎖線）と約 $30 \mathrm{~s}$ (二点鎖線）の時定数の成分で近似 でさる。LLNLの試験結果は原研の試験結果を補完 しており，両者ともに同じ傾向を示す。

損失曲線をさらに詳細にみると, 規格化損失は同じ 立ち上げ時間でもわずかに曲線からずれる。これは， 交流損失の值が台形波のフラットトップ時間に依存し ているためである。この関係をみるために，式(2)を 用いて立ち上げ時間 $20 \mathrm{~s}$ の場合の規格化損失とフラ ットトップ時間の関係を計算した結果を Fig. 3 に示 す。フラットトップ時間が長時定数の時間以上に長く なると，交流損失も増加することが分かる。この傾向 はTable 2 の結合損失值からも測定誤差を考慮すれ ば確認できる。

これらの事実から, SMES モデルコイルの結合損 失は少なくとも 2 つ以上の時定数の成分から成り立っ ていることが確認できる。このうち，0.22 s の短時定 数の成分は, 実導体の短尺試料の結合損失結果と一致 する ${ }^{11)}$ 。他方，長時定数の成分は，コイルにすること により初めて現れるもので, 平均的に $4 \mathrm{~m}$ 程度の結 合電流のループから発生しているものと推測され た ${ }^{11)}$ 。このため, LLNL 試験においては, コイルに ホール素子を取り付けて結合損失電流ループの磁界測 定を行うことにより，長時定数成分の検証を試みた。 


\section{SMES モデルコイルの結合電流ループ}

結合電流ループは素線間で構成されると仮定する と，本コイル導体の場合，素線が撚られているため， 電流ループにより発生する磁界方向は撚りの効果によ り種々の方向を持つことになる。ループが発生する磁 界を測定するホール素子は，Fig. 4 に示すように， 強大な主磁界の影響を受けないように主磁界に平行に 配置して,ループ電流による微弱な磁界を測定した。 位置はコイル上面と内径面の 2 力所であり，それぞれ 3 個のホール素子を配列した。

コイル上面に配列したホール素子の出力波形とコイ 儿通電電流波形の 1 例を代表的な波形として Fig. 5 に示す。ホール素子は数 $100 \mathrm{G}$ 程度の主磁界の影響を 受けている。図から，電流がフラットトップの領域に 入ると, 結合電流ループによる磁界の減衰を観測し, また，電流が完全にゼロになった後でも同じループに よる磁界の減衰を観測した。ループの磁界減衰波形か ら, 最初に $3.8 \mathrm{~s}$ 程度の時定数を持つループの磁界が 減衰し, 続いて $100 \mathrm{~s}$ 程度の時定数を持つループの磁 界 $(3.8 \mathrm{~s}$ の場合とは方向が逆) が減衰していること が分かる。また，同じホール素子の出力波形は励磁速 度が $500 \mathrm{~A} / \mathrm{s}$ までほぼ同じ時定数を示した。したがっ て, 何らかの原因で形成されたループには, 主磁界を シールドするように循環する結合電流が誘起される。 これらのループに流れる結合電流が長時定数の交流損

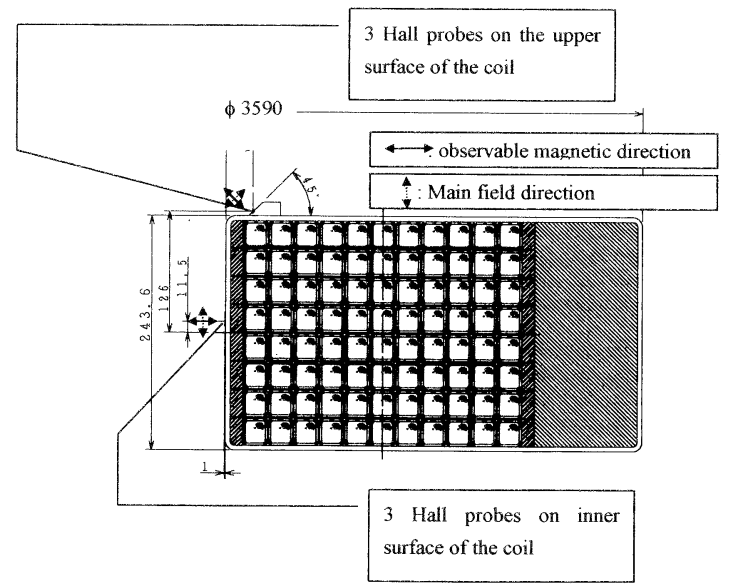

Fig. 4 Locations of Hall probes detecting small field caused by coupling currents of long time constants.
失を引き起こしている主要因と考えられる。

他のホール素子の出力からも, 長時定数が 2 つ程度 の成分から成り立っていることが観測された。短い方 は約 $4 \mathrm{~s}$ 程度であり, 長い方は $50 \sim 110 \mathrm{~s} て ゙$ 平均的に 約 $80 \mathrm{~s}$ 程度の長時定数成分が観測された。これらは 2 力所のホール素子の位置で測定した結果であり, 実 際には非常に多くのループがコイル内で構成されてい ることが予想される。

これらのループの特性長 $L_{2}$ は, 等価抵抗が短時定 数と同じであると仮定すると，下式で与えられる。

$$
L_{2}=L_{1} \sqrt{\frac{\tau_{2}}{\tau_{1}}}
$$

ただし， $L_{1}$ は最終撚りピッチ，ては時定数で, 添え字 1 は短時定数, 2 は長時定数を表す。代表的な $4 \mathrm{~s}$ と $80 \mathrm{~s}$ の長時定数に対する特性長としては,

$$
\begin{aligned}
& \tau_{2}=4 \mathrm{~s}: L_{2}=1.5 \mathrm{~m} \\
& \tau_{2}=80 \mathrm{~s}: L_{2}=6.9 \mathrm{~m}
\end{aligned}
$$

程度が得られる。また, これらの值を平均した特性長 は $4 \mathrm{~m}$ 程度となり, 時定数 $30 \mathrm{~s}$ の場合の值とほぼ一 致する。

一方，このようなループに流れる電流は，いわゆる Ramp Rate Limitation（RRL）を引き起こす偏流と 同じ性質のものであると考えられる ${ }^{15,16)}$ 。本コイルで RRL 特性に起因するクエンチが観測されなかったの は，励磁速度が RRL を誘起するほど速くない，およ び本コイルの安定性が非常に高いことによると考えら れる。また，加速器で観測された長時定数を有する Supercurrents，あるいは Boundary-induced coupling currentsも同じ原因と考えられる ${ }^{17)}$

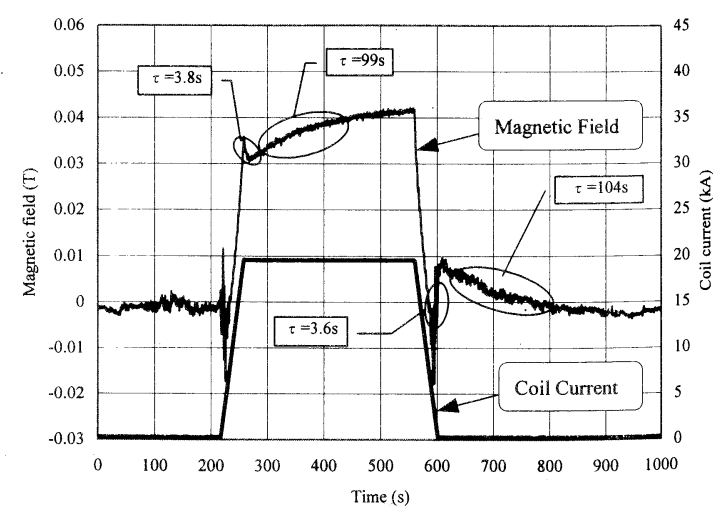

Fig. 5 Magnetic field detected by Hall probe and coil current waveform.

低温工学 
このような長時定数のループが形成される原因は 種久検討され, 加速器用導体では相当に明白になって きたが ${ }^{17)}, \mathrm{CIC}$ 導体では導体構成の複雑さのため多く の可能性が示唆されている段階で15,18), まだ, 決定的 な結論に達してはいない。

\section{5. 改良導体}

SMES モデルコイルでは，コイル形状になって初 めて現れる長時定数に起因する交流損失のために，短 尺試験結果から予想した交流損失より大きな值となっ た。この長時定数の結合損失成分は, 何らかの原因で 素線間に形成されたループに発生する結合電流が素線 間を渡るときに引き起こす結合損失であると推定され る。したがって，素線間の接触抵抗を高くすることに より，長時定数に起因する損失の低隇が期待できる。

素線間の接触抵抗を高くする代表的な方法として, 素線の表面に $\mathrm{CuNi}$ などの高抵抗層を被覆する方

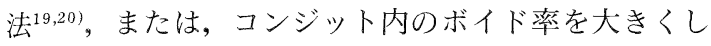
て素線間の接触を少なくする方法などが考えられ る ${ }^{21)}$ 。改良導体には, 確実に接触抵抗を高くできる $\mathrm{CuNi}$ 高抵抗層被覆素線を選んだ。

改良導体の主要諸元は, Table 3 に示すように, SMES モデルコイルに対して素線の構成・銅比など が若干異なるが, 幾何学的寸法はできるだけ等しくし た。この素線でSMES モデルコイル用導体の $1 / 4$ の 断面に相当する 5 次撚り線のケーブルを製作し，それ をステンレス鋼のコンジットに挿入して改良導体を構 成した。然りピッチはSMES モデルコイルと同じに した。

この改良導体を用いて直径 $340 \mathrm{~mm}$, ターン数 18, 全導体長約 $20 \mathrm{~m}$ の小コイルを製作した。コイルは浸 漬冷却型バックアップコイルのボア内に設けた真空空 間内に設置して，交流損失を測定した。計測方法は工 ンタルピー法で, 抵抗ヒータの入力と比較して較正し た。試験は, バックアップコイルを励磁した後ホール ドし，その後に電流遮断で小コイルに磁界変化を与え

Table 3 Main parameters of the improved CIC conductor.

\begin{tabular}{ll} 
Strand diameter & $0.62 \mathrm{~mm}$ \\
Twist pitch & $6.2 \mathrm{~mm}$ \\
Coated material & $\mathrm{CuNi}(34 \mu \mathrm{m})$ \\
Cu/CuNi/NbTi ratio & $4.7 / 2.5 / 1$ \\
Cable configuration & $3 \times 3 \times 3 \times 3 \times 3=243$ \\
\hline
\end{tabular}

Vol. 34 No. 6 (1999)
て測定した。磁界の変化速度は保護抵抗の値と電流值 を変えて行った。

また，小コイルでも，LLNLで試験した場合と同 様に, 長時定数成分を計測するためのホール素子を取 り付けた。しかし, 試験では最も早い $30 \mathrm{~s}$ の遮断時 定数より長い時定数の磁界減衰波形を観測することが できなかった。すなわち, CuNi 被覆をした改良導体 では, 少なくとも 5 次撚り線構成では長時定数の成分 は少ないと推定される。

このことから，SMES コイルで観測されたような $4 \mathrm{~m}$ 程度の長い結合電流のループは少なく, 結合損 失は最終撚りピッチ長の 2 乗に比例する成分が主成分 と考えられる。したがって，小コイルの結合損失結果 を SMES 導体と比較するために, 最終撚りピッチ長 の換算をすると，結合損失は約 35〜60 ms になる。 この值は，別に製作した 6 次撚り線構成の改良導体の 短尺試料による結合損失測定結果の約 $17 \mathrm{~ms}$ と比較 して若干大きくなっている。この原因として，小コイ ルのボイド率が $36.0 \%$ で短尺試料の $37.0 \%$ より少な くなったため, 素線間の接触抵抗が減少したことが主 要因と考えられる ${ }^{21}$ 。

最終の 6 次撚り線構成でも長時定数の成分が少ない と仮定し, 規格化損失 $Q^{*}$ と立ち上げ時間の逆数との 関係を求めた結果を, Fig. 6 に白抜きの四角形で示 す。図中には, SMES モデルコイルの試験結果も併 せて揭載した。図から, SMES モデルコイルの短時 定数 $0.22 \mathrm{~s}$ と比較して, 約 $1 / 4$ に低減されているの が分かる。また, 長時定数の成分がないため, 結合損 失は立ち上げ時間の逆数が $0.1 \mathrm{~Hz}$ の位置で約 $1 / 6$, $0.01 \mathrm{~Hz}$ で約 $1 / 20$ に低減されているのが分かる。こ

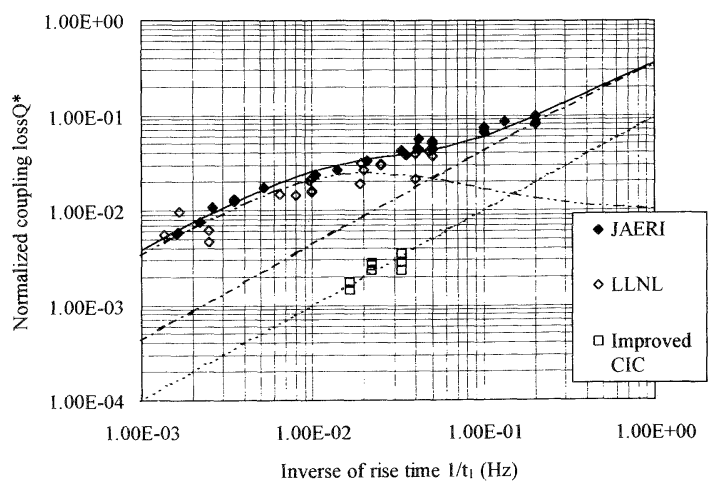

Fig. 6 Normalized coupling loss of the improved CIC conductor as a function of $1 / t_{1}$. 
のことから, CuNi 被覆の効果により接触抵抗が増加

し，交流損失を低減できることが確認できた。

一方, 超電導コイルを安定に運転するためには十分 な安定性が要求され, 一般的には, 安定性は交流損失 低減とトーレードオフの関係にある。ここでは，導体 の安定性を調べるために，ケーブルの素線間インピー ダンスの周波数特性を測定して検討した ${ }^{22)}$ 。 $1 \mathrm{kHz}$ における改良導体のインピーダンスは約 $0.1 \mathrm{~m} \Omega$ であ り, 安定に運転できたクロム被覆素線の導体のインピ ーダンス約 $1 \mathrm{~m} \Omega$ と比べて約 1 桁ほど低かった。し たがって, 改良導体は交流損失が低減され，かつ安定 に運転可能であると予想される。

\section{6. ま と め}

SMES モデルコイルの原研およびLLNL での一連 の交流損失試験結果から，次のことが分かった。

1）LLNLでの測定結果は交流損失値，およびその 特性ともに原研で得な結果と一致した。これにより， 原研での試験結果の妥当性を実証した。

2) SMES モデルコイルの結合損失は，規格化損失 の周波数依存性から, 短時定数と長時定数成分とで構 成されることを再確認した。

3）長時定数の存在は，台形波通電波形のフラット トップ時間を変えることにより，結合損失が変化する ことからも確認できた。

4）長時定数の存在の決定的な証拠は，ホール素子 を用いて導体内の結合電流ループが発生する微弱磁界 を観測できたことで示される。また，磁界減衰波形か ら,これらのループは種々の時定数を持つループから 構成されていることも分かった。

交流損失低減のために, $\mathrm{CuNi}$ 被覆素線を用いた縮 小改良導体で小コイルを製作し，交流損失を測定した 結果，次のことが分かった。

1）立ち上げ時間が $10 \mathrm{~s}$ 程度の場合，損失を約 $1 / 6$ 程度まで低減できた。これにより，CuNi 被覆導体は 確実に結合損失を低減できることが確認できた。

2）小コイルでは結合損失の長時定数は観測されな かった。

以上のことから, 今後の課題として次のことが挙げ られる。

1）長時定数の結合損失ループが存在することが実 証できたので，今後はそのループが形成される原因を 研究する必要がある。

2）長時定数のループは，いわゆる $\mathrm{CIC}$ 導体に発生
する RRL現象や, 加速器で観測される Supercur. rents と同じ現象であると推測され，それらを統一的 に説明することが重要な課題である。

3）高抵抗層 $\mathrm{CuNi}$ 被覆素線は交流損失低減に有効 であることが分かり, かつ安定性も素線間のインピー ダンス測定結果から十分に満足されていることが示さ れたので，今後，実規模サイズで確実に長時定数の交 流損失が低減されていることとあわせて安定性も確保 されていることを示す必要がある。

おわりに，本試験に携わり，ご尽力いただいた多く の方々に感謝の意を表します。また，LLNLでの試 験遂行に当たり K. Thomassen 博士のご尽力に感謝 します。

\section{参考文 献}

1) C.A. Luongo : IEEE Trans. Magn. 32 (1996) 2214

2) E. Masada, et al. : Proc. IEA-Symposium on the Use of Superconductivity in Energy Stor. age, Karlsruhe Germany (1994) 97

3) 山本政弘ら：低温工学 33（1998）454

4) Y. Murakami, et al. : Proc. ICEC-16/IMC (1997) 1041

5) T. Satow, et al.: The International Conference on Electrical Engineering '97 (1997) 122

6) 花井 哲ら：低温工学 33 (1998) 460

7) 濱田一弥ら：低温工学 33 (1998) 467

8）礒野高明ら：低温工学 33 (1998) 473

9）和智良裕ら：低温工学 33 (1998) 479

10）伊藤智庸ら：低温工学 33（1998） 485

11）浜島高太郎ら：低温工学 33（1998） 492

12) T. Mito, et al. : IEEE Trans. Appl. Supercond. 7 (1997) 330

13) T. Mito, et al. : Cryogenics 38 (1998) 551

14）船木和夫, 住吉文夫：多芯線と導体, 産業図書, 東京（1995） 35

15) S. Jeong, et al. : Cryogenics 36 (1996) 623

16) M. Takayasu, et al. : IEEE Trans. Appl. Supercond. 7 (1997) 150

17) A. Verweij, et a1. : IEEE Trans. Appl. Supercond. 7 (1997) 723

18) N. Koizumi, et al. : Cryogenics 37 (1997) 441

19) H. Tsuji, et al. : 9th Symp. Engineering Problems of Fusion Research (1981) 2035

20) D. Richter, et al. : IEEE Trans. Appl. Supercond. 7 (1997) 786

21) A. Nijhuis, et al. : IEEE Trans. Magn. 32 (1996) 2743

22）小野通隆ら：低温工学 31（1996） 518 